\title{
EFFECT OF ARGON ION IRRADIATION ON HARDENING AND MICROSTRUCTURE OF FERRITIC-MARTENSITIC STEEL T91
}

\author{
V.N. Voyevodin ${ }^{1,2}$, G.D. Tolstolutskaya ${ }^{1}$, S.A. Karpov ${ }^{1}$, M.A. Tikhonovsky ${ }^{1}$, \\ G.N. Tolmachova ${ }^{1}$, A.S. Kalchenko ${ }^{1}$, R.L. Vasilenko ${ }^{1}$, I.E. Kopanets ${ }^{1}$ \\ ${ }^{1}$ National Science Center “Kharkov Institute of Physics and Technology”, Kharkov, Ukraine; \\ ${ }^{2}$ V.N. Karazin Kharkiv National University, Kharkov, Ukraine \\ E-mail: karpofff@kipt.kharkov.ua
}

Ferritic-martensitic steel T91 was irradiated with $1.4 \mathrm{MeV} \mathrm{Ar}^{+}$ions to doses from 0.5 to 7 displacements per atom (dpa) at room temperature. Microstructure characterization was performed using transmission electron microscopy (TEM). TEM observations indicated that black dots and dislocation loops dominated the damage microstructure after ion irradiation. The nanoindentation technique was used to find out the changes in the hardness values with irradiation dose. Nanoindentation tests were performed at room temperature in continuous stiffness measurement mode before and after the irradiation. Nix-Gao model was used to extract the bulk-equivalent nanohardness of specimens. Pile-up of material around the indentation site that affects the calculated contact area was taken into account for correct interpretation of the mechanical properties of the irradiated material. It is shown that ion irradiation leads to hardening by $21 \%(\Delta H \sim 0.7 \mathrm{GPa})$ which reaches quasi saturation at doses $\geq 1 \mathrm{dpa}$.

\section{INTRODUCTION}

The safety is one of the most pressing issues in the nuclear power industry. Therefore the reactors of the 3rd generation currently under construction, and the designed reactors of the 4th generations are becoming safer to operate, more reliable, more resource efficient, more environmentally friendly and more economical. Prospective nuclear applications like Generation IV fission and fusion reactors cause new materials challenges from the point of view of higher neutron exposures and operating temperatures.

Ferritic-martensitic steels are the primary candidate materials for structural components in such high dose nuclear applications. Compared to austenitic stainless steels, F-M alloys exhibit high resistant to neutron irradiation, in terms of reduced irradiation swelling. In addition, these steels also have higher thermal conductivity, lower thermal expansion coefficients, good creep behavior, high strength at elevated temperatures, and lower cost [1].

The radiation-induced microstructural modifications significantly change the properties of the materials. The major damage effects under irradiation include radiation-induced segregation, radiation-induced precipitation, dislocation evolution, and swelling [2]. For high chromium F-M steels, the most notable radiation effect is the degradation in mechanical properties through irradiation hardening and embrittlement at low temperatues $\left(<160{ }^{\circ} \mathrm{C}\right)$. Significant hardening can occur as early as $0.01 \mathrm{dpa}$ [3].

Understanding the microstructural evolution and its effect on the degradation of mechanical properties are of utmost importance. High damage neutron-irradiated samples are difficult to come by, as it takes a long time to irradiate samples. A typical damage rate for neutrons is on the order of $10^{-8} \mathrm{dpa} / \mathrm{s}$. Moreover many nuclear facilities are now shut down (FFTF, RAPSODIE, DFR, PFR, Superfenix, EBR-II, BR-10, BN-350 etc).

The use of heavy ion implantation for the simulation of neutron irradiation under reactor conditions is common practice, due to the short time scales to reach relatively high damage levels and the absence of induced radioactivity. Therefore, both proton and heavy ion irradiations $\left(10^{-6}\right.$ and $10^{-3} \mathrm{dpa} / \mathrm{s}$ respectively) are being used to emulate neutron damage in a much faster and cost effective way.

However ion irradiation has a significant drawback shallow depth of damage layer that making it difficult to investigate the mechanical properties. The solution of problem is possible by using nanoindentation, transmission electron microscopy and scanning electron microscopy (SEM) - small scale methods which can be used to investigate the changes of microstructure and mechanical properties due to irradiation in small volumes.

In the presented work, we applied these methods to investigate the changes in the mechanical properties in ferritic-martensitic T91 steel caused by high energy argon ions irradiation. A limited number of previous studies have been performed under fast reactor and low temperature spallation environments [4-6]. Several studies have been performed on the response of mechanical properties of T91 to ion irradiation [7-13]. The scattered data were obtained for individual values of damage doses, different irradiation temperatures (from room temperature (RT) to $600{ }^{\circ} \mathrm{C}$ ) and the types and energies of the irradiating particles.

The aim of the present work is to determine the dose dependent hardness and evolution of microstructure of T91 steel irradiated with accelerated ions to moderate doses (up to $7 \mathrm{dpa}$ ) at room temperature using nanoindentation testing over a large range of indentation depths and pile-up correction as well as consideration of both the indentation size effect and the substrate effect.

\section{EXPERIMENTAL DETAILS}

The experiments were carried out on T91 ferriticmartensitic steel of composition $9 \mathrm{Cr}-1 \mathrm{Mo}$ with minor alloying elements of $\mathrm{Ni}, \mathrm{Nb}, \mathrm{V}$, and $\mathrm{C}$. The material was supplied by INDUSTELL, Belgium (melting: 504/3, heat: 82566-4). The material was delivered as hot rolled and heat treated plates with a thickness of $40 \mathrm{~mm}$. The 
heat treatment consisted of a normalization treatment at $1040{ }^{\circ} \mathrm{C}$ for $30 \mathrm{~min}$ followed by air cooling and then tempered at $730{ }^{\circ} \mathrm{C}$ for $60 \mathrm{~min}$ followed by air cooling to room temperature. The chemical composition of the as-received material is given in Tabl. 1. Samples of dimensions $10 \times 10 \times 2 \mathrm{~mm}$ were cut from the material using wire-cut electrical discharge machining. Surfaces of the samples were mechanically polished initially with sandpapers of varying grits and finally electrolytically polished using $95 \%$ methanol and 5\% perchloric acid solution at a temperature of $-30 \mathrm{C}$ with an applied voltage of $20 \mathrm{~V}$.

Table 1

Chemical composition of T91 steel delivered by Industeel (wt.\%)

\begin{tabular}{|c|c|c|c|c|c|c|c|c|c|}
\hline \multirow{2}{*}{ Fe (bal.) } & $\mathbf{C r}$ & $\mathbf{M o}$ & $\mathbf{M n}$ & $\mathbf{S i}$ & $\mathbf{V}$ & $\mathbf{~ N i}$ & $\mathbf{N b}$ & $\mathbf{C u}$ & $\mathbf{A l}$ \\
\cline { 2 - 10 } & 8.76 & 0.862 & 0.597 & 0.317 & 0.186 & 0.099 & 0.073 & 0.054 & 0.021 \\
\hline \multirow{2}{*}{ T91 } & $\mathbf{C}$ & $\mathbf{N}$ & $\mathbf{P}$ & $\mathbf{S}$ & $\mathbf{S n}$ & $\mathbf{B}$ & $\mathbf{C o}$ & $\mathbf{A s}$ & - \\
\cline { 2 - 10 } & 0.088 & 0.003 & 0.019 & 0.0006 & 0.005 & 0.0001 & 0.019 & 0.007 & - \\
\hline
\end{tabular}

Samples were irradiated with $1.4 \mathrm{MeV}$ argon ions in a range of doses $0.5 \ldots 7 \mathrm{dpa}$. All irradiations were carried out with accelerating-measuring system "ESU2" [14], which contain Van de Graaf accelerator. The irradiation was performed at room temperature. The depth distribution of $\mathrm{Ar}$ atoms concentration and damage was calculated by SRIM 2008 [15] and shown in Fig. 1. The damage calculations are based on the Kinchin-Pease model, with a displacement energy of $40 \mathrm{eV}$ for $\mathrm{Fe}$ and $\mathrm{Cr}$, as recommended in ASTM E52196 (2009) [16].

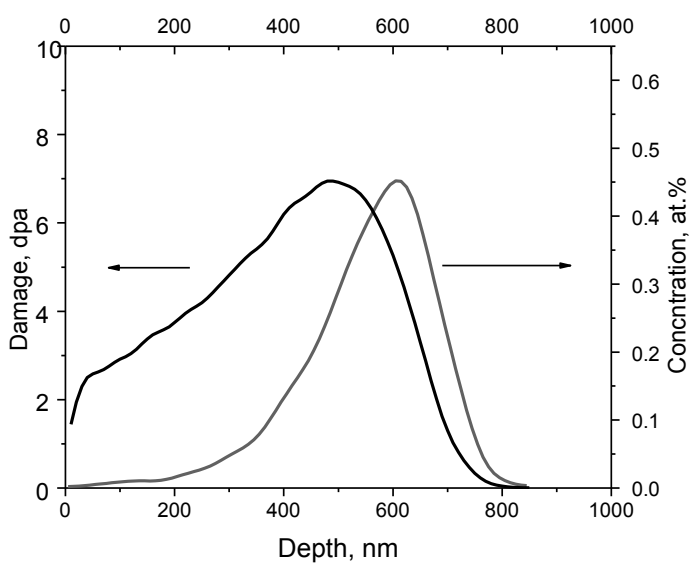

Fig. 1. Calculated profiles of damages and concentrations of $1.4 \mathrm{MeV}$ Ar ions implanted in T91 steel to a dose of $1 \cdot 10^{16} \mathrm{~cm}^{-2}$

Nanohardness was measured by Nanoindenter G200 with a Berkovich type indentation tip. A 'continuous stiffness measurement method' was used [17], which produces mechanical property data as a function of indenter depth. Tests were performed with a constant deformation rate of $0.05 \mathrm{~s}^{-1}$. Each sample was applied at least 10 prints at a distance of $35 \mu \mathrm{m}$ from each other. Nominal maximum displacement of $2000 \mathrm{~nm}$ was used for all measurements on unirradiated and ion-irradiated steel. The methodology of Oliver and Pharr was used to find the hardness [18].

TEM in kinematic bright-field mode was primarily used to characterize radiation-induced structures. Secondary electron images produced in the SEM were used for investigations of as-received and irradiated specimens in regions surrounding indents.

\section{RESULTS AND DISCUSSIONS}

TEM observation of unirradiated samples (Fig. 2) showed dual phase morphology containing ferrite and martensite phases. The two phases could also be identified by the difference in the dislocation density. High dislocation density was observed in the martensite regions, whereas ferritic regions were relatively free from dislocations. In addition, the presence of several precipitates in the microstructure of T91 steel was also noticed. Elemental analysis of several large precipitates using energy-dispersive spectroscopy (EDS) attached with TEM showed high concentrations of $\mathrm{Cr}$ and $\mathrm{Fe}$ in ones (Tabl. 2).

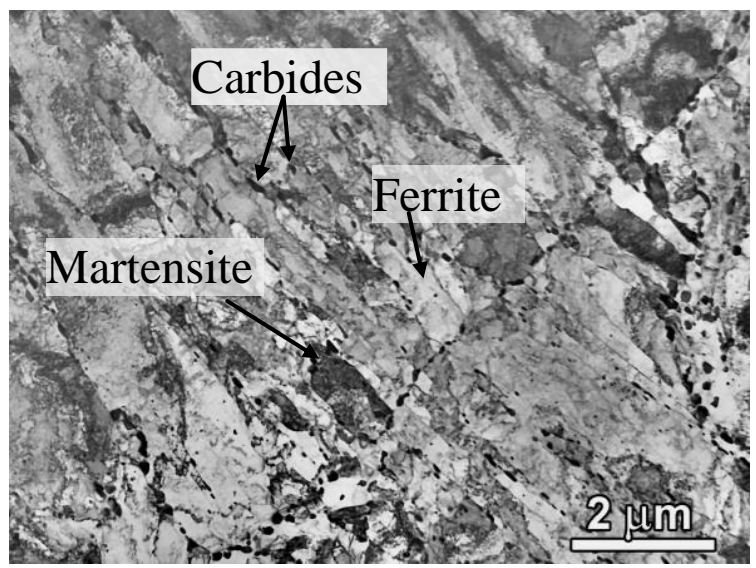

Fig. 2. Microstructure of the unirradiated T91

Table 2

Elemental composition of large precipitates provided by EDS analysis

\begin{tabular}{|c|c|}
\hline Element & Mass\% \\
\hline $\mathrm{C}$ & 19.08 \\
\hline $\mathrm{V}$ & 0.12 \\
\hline $\mathrm{Cr}$ & 27.01 \\
\hline $\mathrm{Fe}$ & 46.16 \\
\hline $\mathrm{Mo}$ & 7.63 \\
\hline
\end{tabular}

The indexing of diffraction patterns with different zone axes confirmed that the precipitates investigated were $(\mathrm{Cr}, \mathrm{Fe})_{23} \mathrm{C}_{6}$ type. Majority of the precipitates were formed at ferrite and martensite lath boundaries. In addition, a fraction of precipitates was also found within the grains. The typical size of these precipitates was estimated to be $<100 \mathrm{~nm}$, whereas the size of precipitates at the martensite and ferrite lath boundaries and at the grain boundaries was $100 \ldots .500 \mathrm{~nm}$. It can be assumed that fine precipitates are carbides or carbonitrides of the $\mathrm{MX}$ or $\mathrm{M}_{2} \mathrm{X}$ type.

Irradiated samples showed significant changes in the microstructure as compared to the unirradiated sample. Irradiation-induced defects of very small-sized black 
dots and dislocation loops were observed in the microstructure of the irradiated These defects disappeared upon tilting by small degrees, which clearly indicates that these are not precipitates.

The typical size of these dots in T91 irradiated to $0.5 \mathrm{dpa}$ is about $1 \ldots 3 \mathrm{~nm}$ and estimated localized density of the dots is about $10^{15} \mathrm{~m}^{-2}$. Trends in the literature on the ferritic-martensitic $\mathrm{Fe}-\mathrm{Cr}$ alloys indicated that these black dots are effective traps for point defects. Therefore the dislocation loops were observed with increasing the dose of irradiation (Fig. 3).

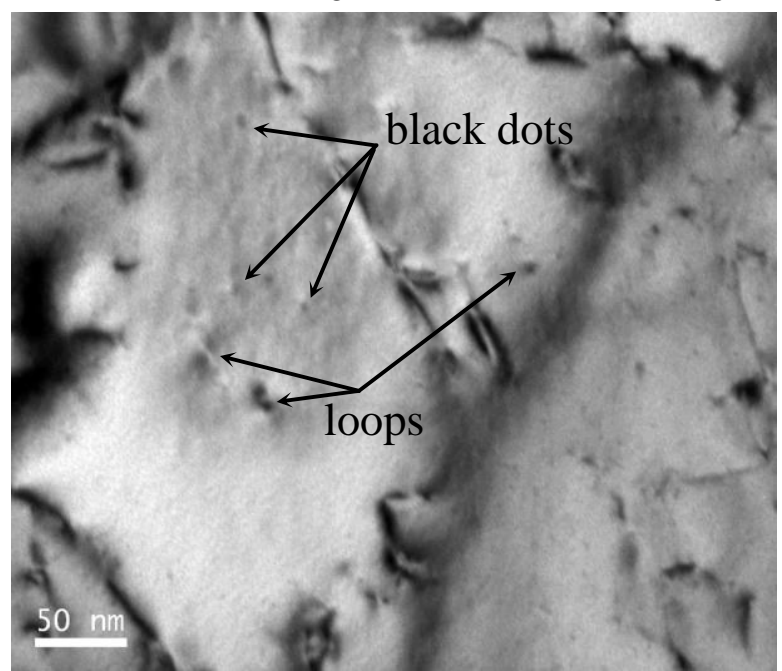

Fig. 3. TEM image showing the microstructure of T91 after irradiation fluence of $1 \mathrm{dpa}$

Fig. 4 shows nanoindentation hardness $(H)$ as a function of indenter displacement $(h)$ of the unirradiated and irradiated T91 steel.

The irradiation of T91 with Ar ions at RT leads to an increase of nanohardness.

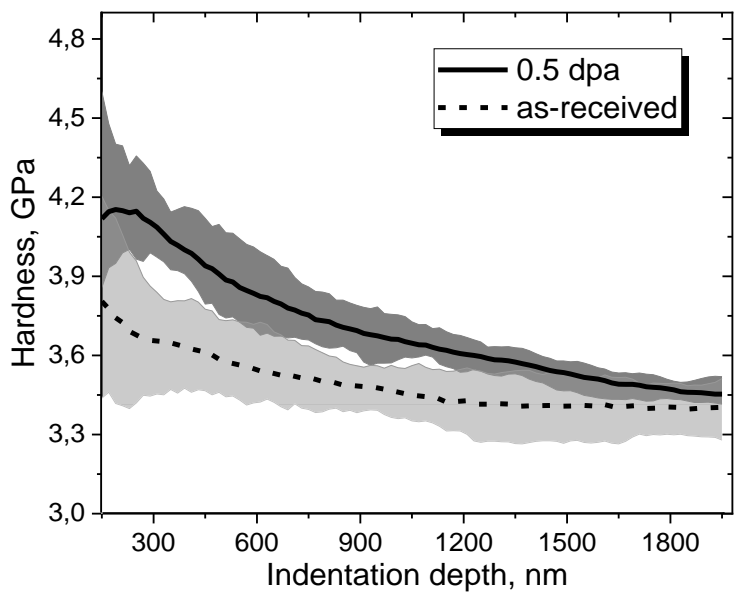

Fig. 4. Nanoindentation hardness vs. indentation depth measured for the unirradiated and irradiated to a dose of 0.5 dpa T91 steel

In all samples, the first $150 \mathrm{~nm}$ of displacement shows a considerable increase in the scatter of the data due to tip-rounding artifacts and surface preparation effects. Therefore, for all samples the first $150 \mathrm{~nm}$ of data will be ignored for the remainder of the analysis.

Generally, indentation hardness of ion irradiated materials represents the superposition of the bulk hardness, indentation size effect (ISE) and the irradiation induced hardening $[19,20]$. The analysis method by nanoindentation measurement is based on the Nix-Gao model [21] that describes the concept of geometrically necessary dislocations required to accommodate the indenter as well as Kasada et al. method [22] that extended model [21] by a filmsubstrate system based on so-called the soft substrate effect. The ion irradiated materials, according to [22], can be considered as "hardened layer-substrate" systems. The unirradiated region below the irradiated region will be plastically deformed before the indenter itself reaches the unirradiated region. The transition point of one area to another represents the critical indentation depth $h_{\mathrm{c}}$, and the bulk equivalent hardness, $H_{0}$ irr , of the ion irradiated region can be obtained by the least square fitting of the hardness data up to a critical depth $h_{\mathrm{c}}$.

By redrawing the hardness profile in terms of NixGao plot (squared hardness vs. reciprocal depth), the bulk-equivalent hardness of the ion-irradiated region has been evaluated as $4.1 \mathrm{GPa}$ for irradiation fluence of 0.5 dpa (Fig. 5). In the case of unirradiated T91, NixGao plot represents virtually straight line due to the lack of radiation-hardened layer; corresponding bulk-equivalent hardness, $H_{0}$ as-received , was estimated as $3.4 \mathrm{GPa}$ (see Fig. 5). For irradiation doses of 1,3 , and $7 \mathrm{dpa}$ the values of $H_{0}$ irr were found to be $3.9,4.15$, and $4.2 \mathrm{GPa}$, respectively.

In this study hardness profiles (see Fig. 4) that have been analyzed for determining the bulk-equivalent hardness, $H_{0}$, of as-received and irradiated T91 steel were obtained from load-displacement data using the method of Oliver and Pharr [18]. This method is adopted as the standard method for the analysis of nanoindentation results. One significant limitation of this method is that it does not account for pile-up or sink-in of testing material around the indent.

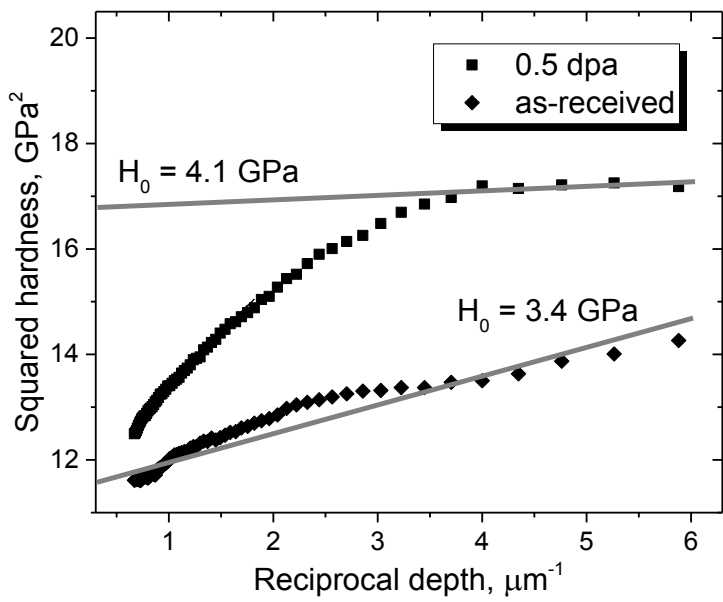

Fig. 5. Nix-Gao plot for unirradiated and argon
irradiated T91 steel

In the case of pile-up, the contact area is greater than predicted by the method that can lead to an overestimation of the indentation hardness. The pileup/sink-in behaviors are dependent on the work hardening rate and the ratio of the elastic modulus to yield strength $\left(E / \sigma_{\mathrm{y}}\right)[18]$.

Recently different methods for pile-up corrected hardness have been proposed. Hardie et al. [8] proposed the approach based on the measurements of actual area 
of contact by scanning electron microscopy (SEM). Pile-up correction (PUC) can then be performed using the ratio of the actual contact area, to the pile-up unaffected area. Heintze et al. [12] suggested the socalled elastic-modulus-based correction (EMC) method to correct nanoindentation hardness data. This method utilizes the square function of indentation modulus to elastic modulus for correction of indentation hardness. An advantage of the EMC method is that one does not require any additional measurements. In [23] was proposed a method to correct nanoindentation hardness that uses the difference in the actual elastic modulus between the ion-irradiated damaged layer and unirradiated material. The disadvantage of this method is that it requires additional transient grating laser measurements. In the following, we will use the concepts of PUC method [8] to evaluate the pile-up effect on ion-irradiation hardening in T91 steel.

After indentation, the hardness impressions were imaged using SEM to measure contact areas and examine the extent of pile-up, in a similar method to that proposed in [24]. Two different contact areas were determined from the SEM images. According to Fig. 6 the pile-up unaffected corner-to-corner area, $\mathrm{A}_{\mathrm{cc}}$, represents the area of the triangle defined by the corners of the hardness impression (see Fig. 6,b,e).

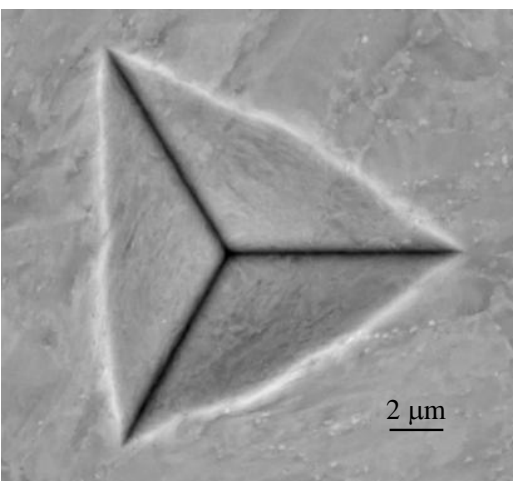

$a$

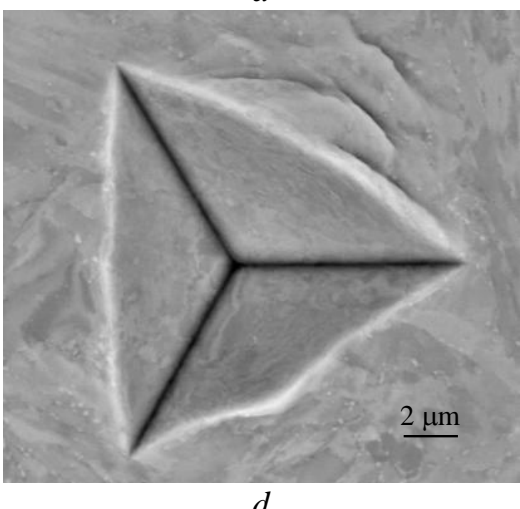

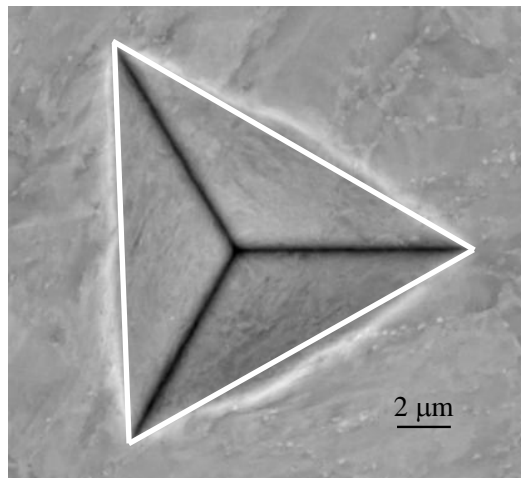

$b$

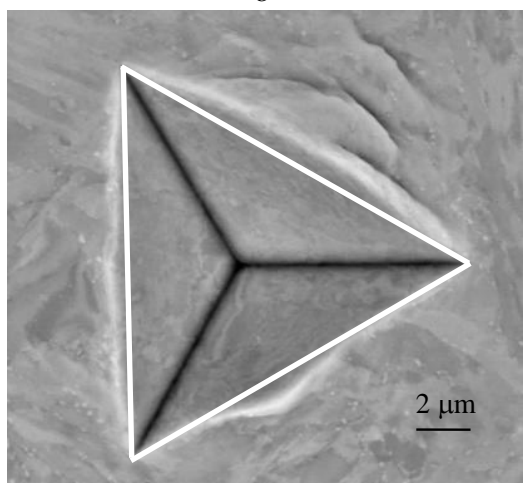

$e$

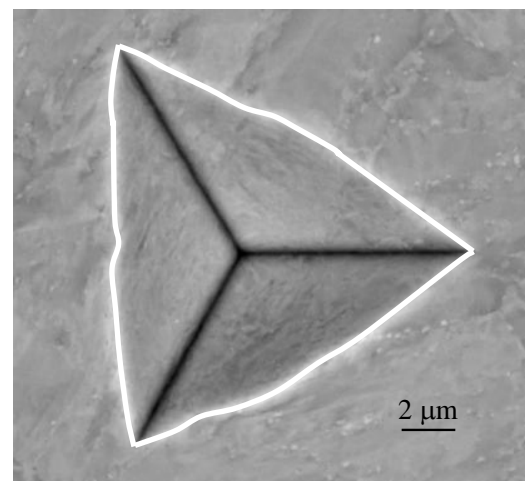

$c$

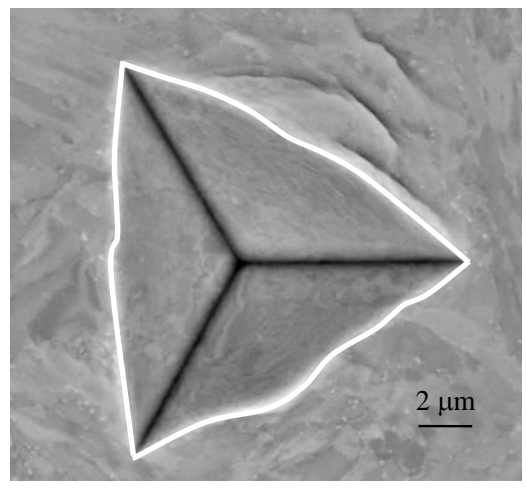

$f$

Fig. 6. SEM images showing deformed regions surrounding indents in un-irradiated $(a, b, c)$ and irradiated $(d, e, f)$ regions. Corner-to-corner $\left(A_{c c}\right)$ of contact area $(b, e)$ and actual $\left(A_{\text {act }}\right)$ contact area $(c, f)$ are shown

The second measure of the contact area was the actual contact area, $A_{\text {act }}$, which includes the extra area contained in the pile-up (Fig. 6,c,f). These specified areas were determined by a digital image processing, and their ratio, $A_{\mathrm{act}} / A_{\mathrm{cc}}$, provided an estimation of the pile-up extent.

Fig. 7 shows the hardness corrected for the actual contact area accounting for pile-up. The values of correction factor, $A_{\mathrm{act}} / A_{\mathrm{cc}}$, were found in the range of $1.10 \ldots 1.18$ and had a statistical scatter for as-received and argon irradiated specimens. The average value of $1.14 \pm 0.04$ correlates well with the EMC factor according to Heintze's approach [12].

Irradiation hardness seems to be saturated at doses $\sim 1$ dpa. Visible defects that obviously cause hardening are defects such as black dots and dislocation loops (see Fig. 3).

In the general case, irradiation hardening was found to be dose-dependent at lower doses and saturated at doses higher than a critical value. The saturation dose was also irradiation temperature-dependent, increasing with increasing irradiation temperature up to $330{ }^{\circ} \mathrm{C}$ and then decreasing apparently at higher irradiation temperatures [6].

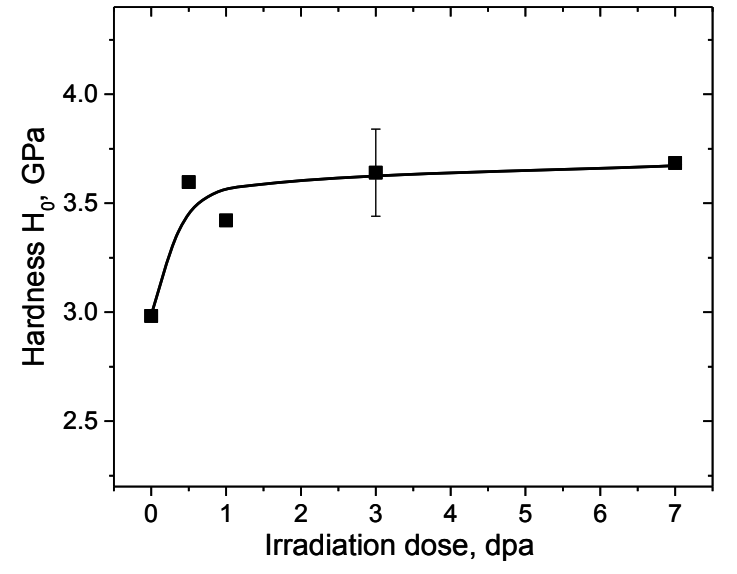

Fig. 7. Corrected for pile-up bulk-equivalent hardness of T91 steel vs. irradiation dose. The solid line is drawn as guide for eyes only 
Ref. [25] represents our previous results of study of irradiation effect with $1.4 \mathrm{MeV}$ argon ions within the range of doses $0 \ldots 10 \mathrm{dpa}$ at room temperature on the hardening of SS316 stainless steel. It was discovered that the sharpest effect is observed at a dose of about $1 \mathrm{dpa}$ with a gradual approach of the quasisaturation mode at high fluencies.

It should be noted that G.S. Was et al analyzing the data of radiation induced radiation hardening of the same heats of proton- and neutron-irradiated 304SS and 316SS have shown that the irradiation hardening of austenitic steels saturates at about a few dpa [26].

The same effect is observed for steel T91. However, in this case hardening is almost two times less indicating a lower probability of embrittlement of ferritic-martensitic steel T91 in comparison with ferritic and austenitic steels.

Comparison of radiation hardening, $\mathrm{H}_{0}$ irr $-H_{0}{ }^{\text {as-received }}$ $=\Delta H$ (values corrected for pile-up), with the results of other authors (Fig. 8) shows some variation in data, which is likely due primarily to the difference in irradiation temperature. A noticeable difference in the data is observed for materials with poles apart microstructures. A clear difference can be seen in the ferritic and tempered martensitic materials (data from [13])

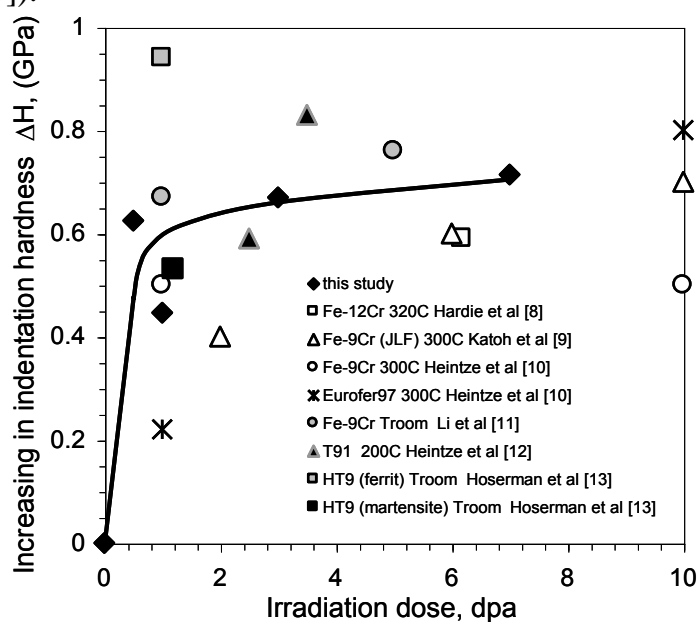

Fig. 8. Radiation-induced relative hardening of T91 steel

It appears that the fine tempered martensitic microstructure has a significant effect in reducing hardening in HT-9 [27]. This can be explained by the fact that the martensitic microstructure which also contains carbides along these boundaries has a high density of interfaces which act as defect sinks for radiation induced defects. This testifies that the materials containing a number of defects or trapping sites suffer less irradiation hardening or embrittlement.

\section{CONCLUSIONS}

Irradiation-hardening behaviors have been investigated for T91 stainless steel after lowtemperature $\left(<100^{\circ} \mathrm{C}\right)$ irradiations. The following conclusions were drawn:

Nanoindentation results showed that irradiation hardening in the ion-irradiated T91 steel was $\sim 0.7 \mathrm{GPa}$ and approach of the quasisaturation mode at fluencies $\geq 1$ dpa.
Visible defects that obviously cause hardening are black dots and dislocation loops.

The hardness was corrected for the actual contact area accounting for pile-up. The values of correction factor, $A_{\text {act }} / A_{\mathrm{cc}}$, were found in the range of $1.10 \ldots 1.18$ for as-received and argon irradiated specimens. The average value of $1.14 \pm 0.04$ correlates well with known in the literature.

The data obtained in the present study indicate that a decrease of ductility of the T91 steel will be expected at fluencies about $1 \ldots .5 \mathrm{dpa}$ where the saturation of the density of the dislocation loops is observed.

\section{REFERENCES}

1. S.J. Zinkle, J.T. Busby. Structural materials for fission \& fusion energy // Mat. Today. 2009, v. 12 p. 12-19.

2. В.Н. Воеводин, И.М. Неклюдов. Эволюция структурно-фазового состояния и радиационная стойкость конструкционных материалов. Киев: «Наукова думка», 2006, 376 с.

3. T.S. Byun, K. Farrell. Irradiation hardening behavior of polycrystalline metals after low temperature irradiation // J. Nucl. Mater. 2004, v. 326, p. 86-96.

4. N. Hashimoto, R.L. Klueh. Microstructural evolution of nickel-doped $9 \mathrm{Cr}$ steels irradiated in HFIR // J. Nucl. Mater. 2002, v. 305, p. 153-158.

5. G. Gupta, Z. Jiao, A.N. Ham, J.T. Busby, G.S. Was. Microstructural evolution of proton irradiated T91 // J. Nucl. Mater. 2006, v. 351, p. 162-173.

6. T. Yamamoto, G. Robert Odette, H. Kishimoto, Jan-Willem Rensman, P. Miao. On the effects of irradiation and helium on the yield stress changes and hardening and non-hardening embrittlement of $\sim 8 \mathrm{Cr}$ tempered martensitic steels: Compilation and analysis of existing data // J. Nucl. Mater. 2006, v. 356, p. 27-49.

7. C.D. Hardie, S.G. Roberts. Nanoindentation of model $\mathrm{Fe}-\mathrm{Cr}$ alloys with self-ion irradiation // J. Nucl. Mater. 2013, v. 433, p. 174-179.

8. C.D. Hardie, S.G. Roberts, and A.J. Bushby. Understanding the effects of ion irradiation using nanoindentation techniques // J. Nucl. Mater. 2015, v. 462, p. 391-401.

9. Y. Katoha, M. Ando, A. Kohyama. Radiation and helium effects on microstructures, nano-indentation properties and deformation behavior in ferrous alloys // J. Nucl. Mater. 2003, v. 323, p. 251-262.
10. C. Heintze
C. Recknagel,
F. Bergner, M. Hernandez-Mayoral, A. Kolitsch. Ion irradiationinduced damage of steels characterized by means of nanoindentation // Nucl. Instrum. Methods Phys. Res. B. 2009 , v. 267, p. $1505-1508$.

11. S. Li, Y. Wang, X. Dai, F. Liu, J. Li, X. Wang. Evaluation of hardening behaviors in ion-irradiated $\mathrm{Fe}-9 \mathrm{Cr}$ and $\mathrm{Fe}-20 \mathrm{Cr}$ alloys by nanoindentation technique // J. Nucl. Mater. 2016, v. 478, p. 50-55.

12. C. Heintze, F. Bergner, S. Akhmadaliev, E. Altstadt. Ion irradiation combined with nanoindentation as a screening test procedure for irradiation hardening // J. Nucl. Mater. 2016, v. 472, p. 196-205.

13. P. Hosemann, C. Vieh, R.R. Greco, S. Kabra, J.A. Valdez, M.J. Cappiello, S.A. Maloy. Nano- 
indentation on ion irradiated steels // J. Nucl. Mater. 2009, v. 389, p. 239-247.

14. Г.Д. Толстолуцкая, В.В. Ружицкий, И.Е. Копанец, В.Н. Воеводин, А.В. Никитин, С.А. Карпов, А.А. Макиенко, Т.М. Слюсаренко. Ускорительный комплекс для изучения поведения гелия и водорода в условиях генерации радиационных дефектов // Problems of Atomic Science and Technology. Series "Physics of Radiation Effect and Radiation Materials Science". 2010, N 1, p. 135-140.

15. http://www.srim.org/

16. ASTM E521-96, 2009, ASTM.

17. G.N. Tolmachova, G.D. Tolstolutskaya, S.A. Karpov, B.S. Sungurov, R.L. Vasilenko. Application of nanoindentation for investigation of radiation damage in SS316 stainless steel // Problems of Atomic Science and Technology. Series "Physics of Radiation Effect and Radiation Materials Science". 2015, N 5(99), p. 168-173.

18. W.C. Oliver, G.M. Pharr. An improved technique for determining hardness and elastic modulus using load and displacement sensing indentation experiments // J. Mater. Res. 1992, v. 7, N 6, p. 15641583.

19. A. Kareer, A. Prasitthipayong, D. Krumwiede, D.M. Collins, P. Hosemann, S.G. Roberts. An analytical method to extract irradiation hardening from nanoindentation hardness-depth curves // J. Nucl. Mater. 2018, v. 498, p. 274-281.

20. S.A. Karpov, G.D. Tolstolutskaya, V.N. Voyevodin, G.N. Tolmachova, I.E. Kopanets. The dose dependence of inert gases irradiation hardening of 316 austenitic stainless steel after low temperature irradiation // Problems of Atomic Science and Technology. Series "Physics of Radiation Effect and Radiation Materials Science”. 2018, N 5(117), p. 34-39.

21. W.D. Nix, H.J. Gao. Indentation size effects in crystalline materials: A law for strain gradient plasticity // J. Mech. Phys. Solid. 1998, v. 46, p. 411-425.

22. R. Kasada et al. A new approach to evaluate irradiation hardening of ion-irradiated ferritic alloys by nano-indentation techniques // Fusion Eng. Des. 2011, v. 86, p. $2658-2661$.
23. C.E. Beck,
F. Hofmann,
J.K. Eliason, A.A. Maznev, K.A. Nelson, and D.E.J. Armstrong. Correcting for contact area changes in nanoindentation using surface acoustic waves // Scr. Mater. 2017, v. 128, p. 83-86.

24. T.Y. Tsui, G.M. Pharr. Substrate effects on nanoindentation mechanical property measurement of soft films on hard substrates // J. Mater. Res. // 1998, v. 14 , p. $292-301$

25. S.A. Karpov, G.D. Tolstolutskaya, B.S. Sungurov, A.Yu. Rostova, G.N. Tolmacheva, I.E. Kopanets. Hardening of SS316 Stainless Steel Caused by the Irradiation with Argon Ions // Materials Science. 2016, v. 52, issue 3, p. 377-384.

26. G.S. Was et al. Emulation of neutron irradiation effects with protons: validation of principle // J. Nucl. Mater. 2002, v. 300, p. 198-216.

27. J. Gao, K. Yabuuchi, A. Kimura. Ionirradiation hardening and microstructural evolution in F82H and ferritic alloys // J. Nucl. Mater. 2019, v. 515, p. 294-302.

Article received 06.03.2019

\title{
ВЛИЯНИЕ ОБЛУЧЕНИЯ ИОНАМИ АРГОНА НА УПРОЧНЕНИЕ И МИКРОСТРУКТУРУ ФЕРРИТНО-МАРТЕНСИТНОЙ СТАЛИ Т91
}

\author{
В.Н. Воеводин, Г.Д. Толстолуцкая, С.А. Карпов, М.А. Тихоновский, Г.Н. Толмачева, \\ А.С. Кальченко, Р.Л. Василенко, И.Е. Копанец
}

Ферритно-мартенситную сталь Т91 облучали при комнатной температуре ионами $\mathrm{Ar}^{+}$с энергией 1,4 МэВ в интервале доз $0,5 \ldots 7$ смещений на атом (сна). Исследование микроструктуры методом просвечивающей электронной микроскопии показало образование после ионного облучения дефектов типа «черных точек» и дислокационных петель. Измерения твердости стали проводили при комнатной температуре методом наноиндентирования в режиме непрерывного измерения жесткости до и после облучения. Извлечение значений объемно-эквивалентной нанотвердости образцов выполнялось с использованием модели НиксаГао. При определении твердости стали учитывали эффект «навала» материала вокруг места вдавливания, который оказывает влияние на расчетную площадь контакта. Показано, что ионное облучение приводит к увеличению нанотвердости на $21 \%(\Delta H \sim 0,7$ ГПа) и достигает квазинасыщения при дозах $\geq 1$ сна.

\section{ВПЛИВ ОПРОМІНЕННЯ ІОНАМИ АРГОНУ НА ЗМІЦНЕННЯ ТА МІКРОСТРУКТУРУ ФЕРИТНО-МАРТЕНСИТНОЇ СТАЛІ Т91}

\section{В.М. Воєводін, Г.Д. Толстолуцька, С.О. Карпов, М.А. Тихоновський, Г.М. Толмачова, О.С. Кальченко, Р.Л. Василенко, І.С. Копанець}

Феритно-мартенситну сталь Т91 опромінювали при кімнатній температурі іонами $\mathrm{Ar}^{+}$з енергією 1,4 МеВ в інтервалі доз 0,5 ..7 зсувів на атом (зна). Дослідження мікроструктури методом просвічувальної електронної мікроскопії показало утворення після іонного опромінення дефектів типу «чорних точок» $\mathrm{i}$ дислокаційних петель. Вимірювання твердості сталі проводили при кімнатній температурі методом наноіндентування в режимі безперервного вимірювання жорсткості до і після опромінення. Значення об'ємно-еквівалентної нанотвердості зразків розраховувалися з використанням моделі Нікса-Гао. При визначенні твердості сталі враховували ефект «навалу» матеріалу навколо місця вдавлення, який впливає на розрахункову площу контакту. Показано, що іонне опромінення призводить до збільшення нанотвердості на $21 \%(\Delta H \sim 0,7$ ГПа) і досягає квазінасичення при дозах $\geq 1$ зна. 